\title{
Improvement of Critical Thinking Ability and Preparedness Assisted by Android-Based Media to Understand Landslide through Physics Learning
}

\author{
Ulfaturrona Nur Labibah $^{1 *}$, Mundilarto ${ }^{2}$, Syazana bt Sulaiman $^{3}$ \\ ${ }^{1,2}$ Universitas Negeri Yogyakarta Jalan Colombo No 1, Yogyakarta, Indonesia \\ ${ }^{3}$ Universiti Putra Malaysia Institut Teknologi Maju (ITMA) 43400, Selangor, Malaysia \\ *Corresponding Address: ulfaturronanurlabibah@gmail.com
}

\begin{tabular}{|c|c|}
\hline Article Info & ABSTRACT \\
\hline $\begin{array}{l}\text { Article history: } \\
\text { Received: February } 01^{\mathrm{st}}, 2021 \\
\text { Accepted: April } 24^{\text {th }}, 2021 \\
\text { Published: April } 30^{\text {th }}, 2021\end{array}$ & $\begin{array}{l}\text { This research aimed to understand the critical thinking ability } \\
\text { improvement and preparedness assisted by Android-based media to } \\
\text { understand landslides through physics learning and understand the } \\
\text { effectiveness of the media. This research provides knowledge about } \\
\text { disaster preparedness through physics learning in landslide-prone schools }\end{array}$ \\
\hline $\begin{array}{l}\text { Keywords: } \\
\text { Media; } \\
\text { Landslide; } \\
\text { Android; } \\
\text { Physics. }\end{array}$ & $\begin{array}{l}\text { Group Design. The research subjects included tenth-grade students in } \\
\text { class X ( } 30 \text { people) at SMA N } 1 \text { Kokap. The samples were selected using } \\
\text { the lottery method and saturated sampling technique to determine the } \\
\text { control and experiment groups (quasi-experimental with Control Group } \\
\text { Design). The pretest and posttest were in the form of essay questions. The } \\
\text { analysis data used independent sample T-test and effect size. The results } \\
\text { show that the average critical thinking ability of the experimental class } \\
\text { increased from } 18.13 \text { to } 65.00 \text {, and the average preparedness increased } \\
\text { from } 68.75 \text { to } 81.88 \text {. The results of the independent sample t-test show the } \\
\text { value of Sig. (2-tailed) on critical thinking ability was } 0.000 \text { and } \\
\text { preparedness was } 0.027 \text { (Sig. (2-tailed) <0.05). Thus, it can be concluded } \\
\text { that there are significant differences in critical thinking ability and disaster } \\
\text { preparedness in the experimental class and the control class. The effect } \\
\text { size of using an Android-based understanding of landslide natural } \\
\text { disasters on students' critical thinking ability and preparedness is } 2.0 \text { with } \\
\text { high effectiveness. Media landslides and landslides through Android- } \\
\text { based physics learning can improve students' critical thinking ability and } \\
\text { disaster preparedness. }\end{array}$ \\
\hline
\end{tabular}

(C) 2021 Physics Education Department, UIN Raden Intan Lampung, Indonesia.

\section{INTRODUCTION}

In Indonesia, rains and landslides often occur, especially in a mountainous area. One of the mountainous areas that are prone to landslides is in the province of Yogyakarta, precisely in Kulonprogo Regency, whose territory is mountainous (Menoreh Hill) at the coordinates of $7^{\circ} 38^{\prime} 42$ "- 759'3" South Latitude and 110 1'37"$110^{\circ} 16^{\prime} 26$ "East Longitude. National Disaster Mitigation Agency (BNPB) stated that landslides in Kulonprogo Regency occurred nine times in 2012. The
Yogyakarta Regional Disaster Mitigation Agency (BPBD) has mapped Kulon Progo Regency as a district with the highest landslide-prone zone than other provinces in Yogyakarta.

Efforts to encourage students' understanding of preparedness require solutions for landslide mitigation, one of which is in the field of education. The lack of disaster preparedness education causes this, so efforts are needed to minimize the damage that will happen (Damanik \& Restu, 2012; Putranto \& Susanto, 2017; 
Wimbardana \& Sagala, 2013). Observing and conducting interviews with three physics teachers who teach at SMA N 1 Kalibawang, SMA N 1 Girimulyo, and SMA N 1 Kokap shows no understanding of landslides in Physics learning because the learning time is minimal. However, efforts are being made in implementing the knowledge of landslide in Physics learning. There is also no disaster preparedness in schools, and materials related explicitly to landslides have not been included in the school curriculum considering that students' residences and the schools are in the landslide-prone location Kulonprogo. Thus preparedness about physical and environmental conditions which have a high risk is essential.

The goal is that students are responsive to disasters. The curriculum in disaster-prone schools requires an educational curriculum based on local wisdom. (Desfandi, 2014; Syuaib, 2013). The realization requires an understanding of disaster itself. Disaster understanding by students whose school is located in the disaster-prone area is beneficial (Parwanto, \& Oyama, 2014; Septikasari, 2018; Setiawati, Rusilowati, \& \& Khumaedi., 2013). Based on integrated science perspectives, a disaster curriculum can be included in schools' learning process, which strongly relates to the disaster. (Honesti \& Djali, 2012). Efforts to grow preparedness in students also need critical thinking in responding to disasters.

The process for obtaining a variety of critical thinking knowledge is contained in cognitive functions and mental activities (Frederick, 2013; Surayya et al., 2014). One of them is scientific knowledge in everyday life. However, students' critical thinking level is still poor because teachers are more dominant in the learning process without involving students actively (Andrisyah, 2018). The result of observations from SMA $\mathrm{N} 1$ Kokap is students tend to be passive towards the teacher when learning takes place. One way for students to be active during the learning process is using media with interesting material that is familiar in everyday life (Azizah, et al., 2015; Mustofa \& Rusdiana, 2016). One of which is a media to understand landslide. Learning resources are developed with disaster-based physics material (Anggraini et al., 2017). The physics material referred to in the curriculum is about effort and energy, which can be applied in learning media by utilizing technology.

The advancement of technology can be developed for educational purposes, one of which is Android-based application because nowadays, many students already use smartphones. The Android operating system on a gadget is open source which can be developed more quickly than Symbian, iOS, or Windows. Learning physics with an Android-based application can encourage students to understand the material's content and improve their understanding (Marhadini et al., 2017). Android-based applications have a role as a medium for sharing information about natural disasters and mitigation (Nadian et al., 2015; Winarni et al., 2018). Android-based application in the learning process can also improve critical thinking ability (Astuti et al., 2018; Ismail \& Harun, 2016; Mulhayatiah et al., 2019). Android-based applications in the learning process can also improve critical thinking skills (Astuti et al., 2018; Ismail \& Harun, 2016; Mulhayatiah et al., 2019). Students' critical thinking ability and disaster preparedness using Android-based applications can be increased. Still, in implementation, it is not in disaster-prone schools (Rahmawati et al., 2020), so it would be more appropriate if the media could be implemented in disaster-prone school areas, for example, in Kulonprogo. However, learning activities in Kulonprogo Regency schools do not optimize technology utilization, primarily based on Android.

Refers to it, efforts to improve critical thinking ability in learning physics, especially concerning natural disaster preparedness in school's landslide-prone to 
use Android-based application. An Androidbased application eases the teacher and students to access offline. It can be used as a learning medium in physics, especially in landslide-prone areas where the dominant signal is minimal to access the internet for using media. The media includes physics material and landslide disaster preparedness equipped with button features containing significant numbers for landslide emergency calls, disaster response videos, and learning evaluations consisting of material questions during the learning process. This research aims to 1) understand the improvement of critical thinking ability and preparedness assisted by Android-based media to understand landslides through physics learning, 2) understand the effectiveness of the media.

\section{METHODS}

The research used quasi-experimental with Control Group Design (Sugiyono, 2012) are shown in Figure 1:

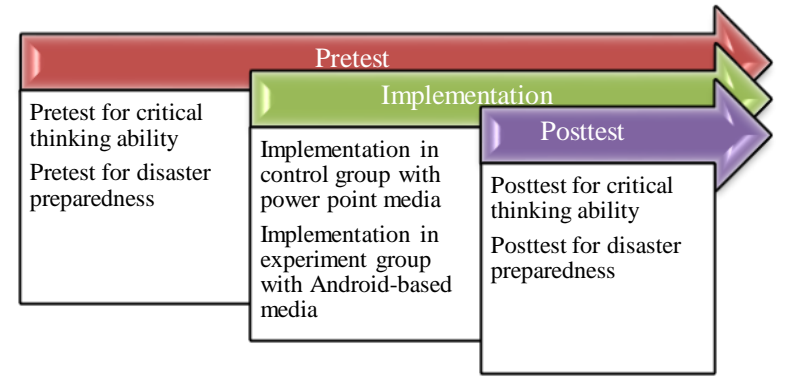

Figure 1. Structure of Method

Each class was chosen using a lottery method and saturated sampling technique with 30 students class X MIA at SMA N 1 Kokap with students age 15-16 years old and given a pretest to find out the differences between the two classes in the initial state. The experimental class was treated with Android-based media and given a posttest to know the effect of the treatment.

This research aims to understand the improvement of critical thinking ability and preparedness assisted by Android-based media to understand landslides through physics learning. Critical thinking ability is measured using five essay questions on the topic of effort and energy. Preparedness was measured using five essay questions. Questions about the validated critical thinking ability and preparedness are shown in Figures 2 and 3,

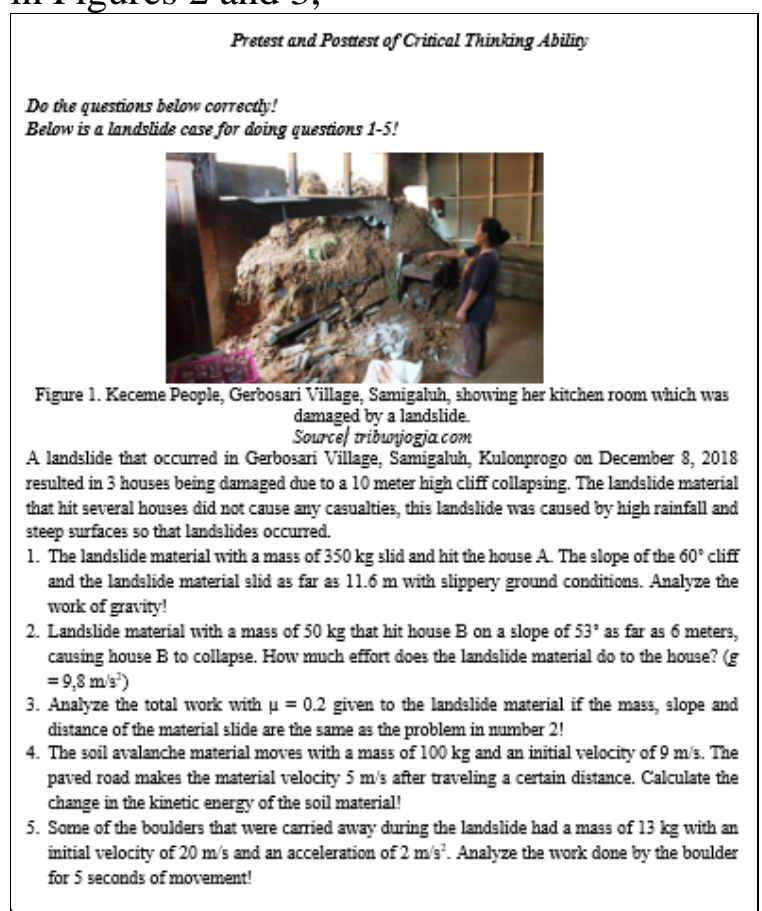

Figure 2. The Critical Thinking Ability Questions According to the Indicator

\begin{tabular}{l} 
Landslide Disaster Preparedness Pretest and Posttest \\
Do the questions below correctly! \\
From BPBD DIY during the rainy season, there are many locations that are prone to \\
landslides, especially in Kulonprogo Regency, including Kokap, Pengasih, Girimulyo, \\
Samigaluh, and Kalibawang districts. Given that there are many landslide-prone locations \\
in Kulonprogo Regency and landslides can occur suddenly, people need to be alert to face \\
disasters when landslides occur appropriately. \\
1. What is a landslide disaster? \\
2. Mention 3 causes that can trigger landslides! \\
3. Explain in a plush way the signs of a landslide that have happened before! (minimum 3) \\
4. What are the impacts of landslides? (minimum 3) \\
5. Mention 3 things that need to be done when a landslide occurs! \\
\hline
\end{tabular}

Figure 3. Display of Preparedness Questions According to the Indicator

The test questions aim to improve students' critical thinking ability, and the landslide disaster preparedness of students can be measured. The test instrument is first validated by expert validation before being used.

In the implementation, this research refers to cognitive, intellectual, and attitude aspects in preparedness to face landslides before, during, and after a disaster. The focus of the implementation of socialization 
and simulation of emergency preparedness. Target implementation at the school prone to landslides in mountainous or hilly regions, especially in Kulon Progo, Yogyakarta, located in the Menoreh hills. Indicators of critical thinking ability (Surayya et al., 2014) are shown in Table 1.

Table 1. Critical Thinking Ability Indicators

\begin{tabular}{|c|}
\hline Indicators \\
\hline $\begin{array}{l}\text { Identifying questions according to events in } \\
\text { everyday life. }\end{array}$ \\
\hline $\begin{array}{l}\text { Knowing the problems that occurred following } \\
\text { the questions given. }\end{array}$ \\
\hline $\begin{array}{l}\text { Concluding the results after solving the } \\
\text { problem given according to the events that } \\
\text { occurred. }\end{array}$ \\
\hline $\begin{array}{l}\text { Explaining the measurement results in solving } \\
\text { problems according to the questions. }\end{array}$ \\
\hline $\begin{array}{l}\text { Setting strategies in analysis and preparation to } \\
\text { solve problems according to questions. }\end{array}$ \\
\hline
\end{tabular}

Validation experts and teachers have validated the media with appropriate and valid results for use in physics learning. Display on the media is in Figures 4 and 5.

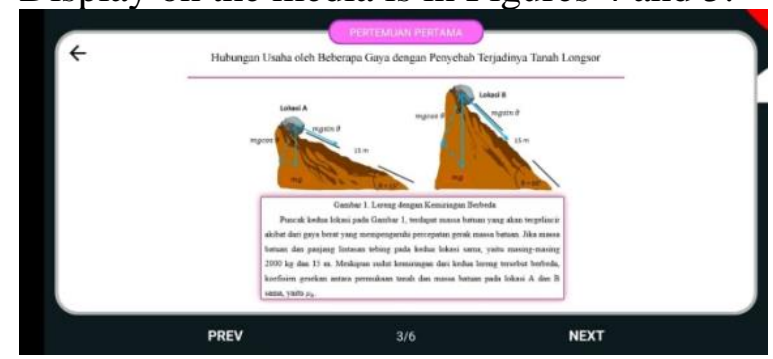

Figure 4. The Media on Physics Material Related to Critical Thinking Ability

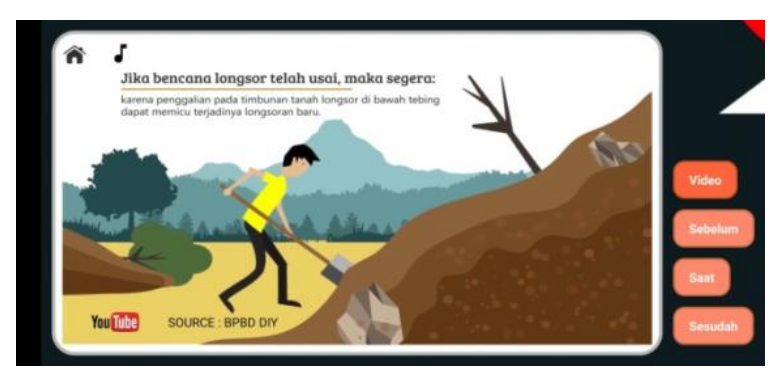

Figure 5. Display of the media on landslide disaster preparedness

Media for understanding landslide natural disasters based on Android can be accessed offline with the extension apk using Android smartphone specifications
(Android 4.0 platform). Media content in the form of business materials and energy, landslide disasters, disaster preparedness, evaluation with pictures and videos to support student's understanding. Media display with images of landslides with several buttons that provide information about how to use the media, silent mode without background music, number information necessary in case of disaster.

Each class was given a pretest before implementation. The experimental class was treated with Android-based media and given a posttest to know the effect of the treatment. The control class was treated with PowerPoint media and given a posttest. The learning model in both classes used ThinkPair-Share (TPS). The research process is in Figure 6.

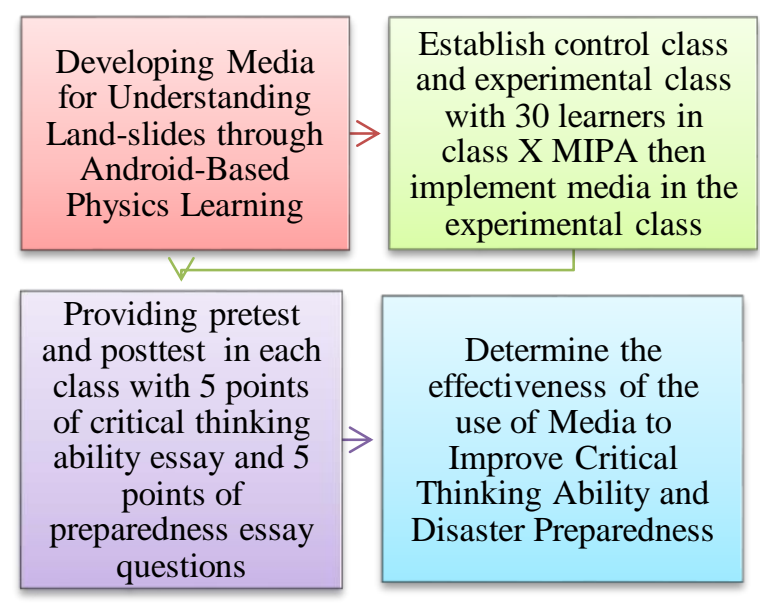

Figure 6. Flow Chart of Research

The improvement of critical thinking ability and landslide preparedness in the experimental and control classes were tested for differences from the pretest and posttest means using the independent sample T-test. The independent sample T-test is a parametric statistical analysis so that the data used must be normally distributed. If not, it is replaced by a non-parametric analysis of the Mann-Whitney test. The difference test phase compares the means of two different sample groups. If the data from each group is normally distributed, the difference test uses the t-test with the formula below. 


$$
t=\frac{\bar{x}_{1}-\bar{x}_{2}}{s_{x_{1} x_{2}} \cdot \sqrt{\frac{2}{n}}}
$$

Description:

$\bar{x}_{1}$ : Means of group 1

$\bar{x}_{2}$ : Means of group 2

$s_{x_{1} x_{2}}:$ Standard deviation of group 1 and 2

$n$ : Total sample from each group

If $\mathrm{t}$ count $\geq \mathrm{t}$ table with degrees of freedom $(\mathrm{db})=2 \mathrm{n}-2$ and a significance level of $5 \%$, then there is a difference in the mean of the two different groups.

Effect size is a method so that the influence or effectiveness of the media on increasing critical thinking ability and student preparedness can be known. Cohen's formula (Thalheimer \& Cook, 2002) was used to calculate the effect size on the Ttest.

$$
S a b=\sqrt{\frac{\left(n_{1}-1\right) s_{1}^{2}+\left(n_{2}-1\right) s_{2}^{2}}{n_{1}+n_{2}-2}}
$$

Description:

$n_{1}$ : the number of samples in the experimental group

$n_{2}$ : the number of samples in the control group

$s_{1}^{2}$ : experimental group variance

$s_{2}^{2}$ : control group variance

The classification of the results from the effect size (Becker, 2000) is as follows in Table 2.

Table 2. Effect Size Classification

\begin{tabular}{cc}
\hline d & Classification \\
\hline $0.8 \mathrm{~d}<2.0$ & High \\
$0.5 \mathrm{~d}<0.8$ & Medium \\
$0.2 \mathrm{~d}<0.5$ & Low \\
\hline
\end{tabular}

\section{RESULTS AND DISCUSSION}

\section{The Improvement of Critical Thinking Ability and Disaster Preparedness}

The analysis results are to determine the increase in critical thinking ability and the preparedness of students in the control and experimental group by comparing the average pretest and posttest scores.

The average analysis of the pretest and posttest can be found in Tables 3 and 4 .
Table 3. The Results of the Average Analysis of the

\begin{tabular}{llcc}
\multicolumn{1}{c}{ Pretest } & & & \\
\hline & Group & N & Mean \\
\hline Critical & Experiment & 16 & 18.13 \\
\cline { 2 - 4 } $\begin{array}{l}\text { Thinking } \\
\text { Ability }\end{array}$ & Control & 14 & 17.14 \\
\hline Preparedness & & & \\
\cline { 2 - 4 } & Experiment & 16 & 68.75 \\
\cline { 2 - 4 } & Control & 14 & 60.78 \\
\hline
\end{tabular}

The pretest results of critical thinking ability in the experimental class were 18.13, and the control class was 17.14. The average pretest preparedness results in the experimental class were 68.75, and the control class was 60.78 .

Table 4. The Results of the Average Analysis of the Posttest

\begin{tabular}{llll}
\hline & Group & $\mathbf{N}$ & Mean \\
\hline Critical & Experiment & 16 & 65.00 \\
\cline { 2 - 4 } $\begin{array}{l}\text { Thinking } \\
\text { Ability }\end{array}$ & Control & 14 & 48.57 \\
\hline Preparedness & Experiment & 16 & 81.88 \\
\cline { 2 - 4 } & Control & 14 & 72.86 \\
\hline
\end{tabular}

The average posttest results of critical thinking ability in the experimental class amounted to 16 students of 65 and the control class amounting to 14 students of 48.57. The average posttest preparedness result in the experimental class was 81.88 , and the control class was 72.86

Based on Tables 3 and 4, the average critical thinking ability and preparedness in both the experimental and control classes is improved. The average critical thinking ability of the experimental class increased from 18.13 to 65.00 , and the average of preparedness increased from 68.75 to 81.88 . The mean from the experimental class is bigger than the control class.

\section{The Effectiveness of Critical Thinking Ability and Disaster Preparedness}

The analysis stage was to determine the differences in the control and experimental classes with different tests, namely the independent sample $\mathrm{T}$-test. The main requirement for the independent sample $\mathrm{T}$ test difference test is that the data must be normally distributed and homogeneous. The effectiveness of the use of the media is 
known by performing the Effect Size analysis. The media is tested in the experimental class. The results from the test are obtained using an independent sample Ttest tested for normality and homogeneity assisted by the SPSS 23 program can be found in Tables 5 and 6.

Table 5. Summary of Difference Test the Result of

\begin{tabular}{clcc}
\multicolumn{3}{c}{ Normality Data and Homogeneity Data } \\
\hline Variable & \multicolumn{1}{c}{ Class } & $\begin{array}{c}\text { Normali } \\
\text { ty }\end{array}$ & $\begin{array}{c}\text { Homogene } \\
\text { ity }\end{array}$ \\
\hline $\begin{array}{c}\text { Critical } \\
\text { Thinking } \\
\text { Ability }\end{array}$ & $\begin{array}{l}\text { Experime } \\
\text { nt }\end{array}$ & 0.064 & 0.181 \\
\cline { 2 - 3 } $\begin{array}{c}\text { Control } \\
\text { Preparedn } \\
\text { ess }\end{array}$ & $\begin{array}{l}\text { Experime } \\
\text { nt }\end{array}$ & 0.255 & \\
\cline { 2 - 3 } & Control & 0.269 & 0.78 \\
\hline
\end{tabular}

Based on Table 5, the Sig. (2-tailed) on the normality data result, namely the experimental class 0.064 (critical thinking ability) and 0.269 (preparedness), and the control class 0.255 (critical thinking ability) and 0.061 (preparedness). The data is normally distributed in both the experimental class and the control class because of Sig. (2-tailed)> 0.05 .

The homogeneity test results showed that critical thinking ability was 0.181 and preparedness was 0.780 , so they were included in the homogeneous data because of Sig. (2-tailed)> 0.05 .

Table 6. The Result of Independent T-test

\begin{tabular}{clc}
\hline Variable & \multicolumn{1}{c}{ Class } & $\begin{array}{c}\text { Independent } \\
\text { T-test }\end{array}$ \\
\hline Critical & Experiment & 0.000 \\
Thinking & Control & \\
Ability & & 0.027 \\
\hline Preparedness & $\begin{array}{l}\text { Experiment } \\
\text { Control }\end{array}$ \\
\hline
\end{tabular}

The results of the independent sample Ttest showed the value of Sig. (2-tailed) on critical thinking, the ability is 0.000 and preparedness 0.027 , so it can be concluded that there are differences in critical thinking ability and preparedness of the experimental class and the control class because of Sig. (2-tailed) $<0.05$.

The results of the effect size analysis using an Android-based understanding of landslide natural disaster media on increasing critical thinking ability and preparedness can be seen in Table 7 .

Table 7. The Results of the Effect Size

\begin{tabular}{ccc}
\hline Variable & Effect Size & Category \\
\hline $\begin{array}{c}\text { Critical } \\
\text { thinking } \\
\text { Ability }\end{array}$ & 2.0 & High \\
\hline Preparedness & 2.0 & High \\
\hline
\end{tabular}

Based on Table 7, the effect size of media use for understanding natural landslide disasters based on Android on students' critical thinking ability and preparedness is 2.0 with significant/high effectiveness.

The relationship of media with critical thinking ability is that students can understand the material of energy business through landslide natural disasters that often occur in landslide-prone areas where they live. Indicators of critical thinking ability are identifying, knowing, analyzing, concluding, and evaluating. Learning with this media encourages students to think logically by identifying examples of cases that exist in the media and can be done through practicum so that students interpret the physics concepts that exist in landslide natural disasters. The relationship between media with disaster preparedness is students can understand what must be done to prepare themselves for landslides before, during, and after a disaster occurs. Preparedness indicators are education, mitigation, preparedness (BNPB, 2013). Students understand landslide natural disasters through explanations from videos on the media and briefly explain how to deal with landslides. After a landslide disaster simulation is carried out, students are more alert and responsive to independent evacuations.

Increased critical thinking ability and preparedness can be achieved using an Android-based understanding of landslide natural disasters media. The final result of the media trial is that it is effectively used because students' critical thinking ability 
and disaster preparedness increase during the learning process. The media is said to be effective if the average grade score increases. There is a difference between the experimental and control classes, and the effect size value is included in the large category (Asyar, 2012).

The difference in student behavior regarding critical thinking ability and disaster preparedness from treatment in each class is that students become more active and think logically when the learning process takes place using landslide understanding media. This research result is aligned with the research on the integration of landslide disaster (Labibah et al., 2019) media whose products are tested on students. The results of the integrated media can improve critical thinking ability (Rahmawati et al., 2020). The research on earthquake disaster integration media (Rany et al., 2020) whose products are implemented to students, then the results of these media can improve disaster preparedness (Abdillah et al., 2020). Integrated disaster education learning can also provide a reference for preparedness and improve disaster mitigation efforts (Abdillah \& Sulaiman, 2020; Desfandi, 2014; Musyarofah, Hindarto, 2013).

\section{CONCLUSION AND SUGGESTION}

The conclusion of this research is a difference in critical thinking ability and preparedness in experiment class and control class. The effect size of using the Android-based understanding of landslide natural disasters on students' essential thinking ability and preparedness with the category of significant/high effectiveness. Android-based media to understand landslide disaster through Physics learning can improve critical thinking ability and preparedness to SMA Negeri 1 Kokap students. There is a need for material updates on the media for understanding landslides and additional research subjects in other landslide-prone schools for recommendations for further research.

\section{REFERENCES}

Abdillah, A. J., Rany, T. D., Kuswanto, H., \& Riyadi, I. (2020). Implementation of physics learning media based on Android integrated earthquake disaster education to enhance problem-solving abilities and natural disaster preparedness. Journal of Physics: Conference Series, 1440(1), 1-8. https://doi.org/10.1088/17426596/1440/1/012027

Abdillah, Annas Jati, \& Sulaiman, S. (2020). Tsunami understanding media: Android-physics mobile learning to improve problem solving-skills and natural disaster preparedness. Jurnal Ilmiah Pendidikan Fisika Al-BiruNi, 9(2), 302-312. https://doi.org/10.24042/jipfalbiruni.v9 i2. 6950

Andrisyah. (2018). Peningkatan kemampuan berpikir kritis dalam pembelajaran sains melalui pendekatan inquiry. Jurnal Tunas Siliwangi, 4(2), 60-70.

Anggraini, S. D., Wahyuni, S., \& Aristya, P. (2017). Pengembangan modul fisika materi gelombang berbasis kebencanaan alam di SMA. Jurnal Edukasi, 4(1), 20-23.

Astuti, I. A. D., Dasmo, D., Nurullaeli, N., \& Rangka, I. B. (2018). The impact of pocket mobile learning to improve critical thinking skills in physics learning. Journal of Physics Conference Series, 1114(1), 1-5. https://doi.org/https://doi.org/10.1088/1 7426596/1114/1/012030

Asyar, R. (2012). Kreatif mengembangkan media pembelajran. Gaung Persada Press.

Azizah, R., Yuliati, L., \& Latifah, E. (2015). Kesulitan pemecahan masalah fisika pada siswa SMA. Jurnal Penelitian Fisika dan Aplikasinya (JPFA), 5(2), 44-50.

Becker, L. A. (2000). Effect size measure for two independent groups. Journal Effect Size Becker.

BNPB. (2013). Indeks risiko bencana 
Indonesia. Journal of Chemical Information and Modeling, 53, 160. https://doi.org/10.1017/CBO97811074 15324.004

Damanik, M. R. S., \& Restu. (2012). Pemetaan tingkat risiko banjir dan longsor sumatera utara berbasis sistem informasi geografis. Jurnal Geografi, 4(1), 29-42.

Desfandi, M. (2014). Urgensi kurikulum pendidikan kebencanaan berbasis kearifan lokal di indonesia. Sosio Didaktika: Social Science Education Journal, 1(2), 177-189. https://doi.org/10.15408/sd.v1i2.1261

Frederick, R. (2013). Encouraging critical thinking in distance learning: Ensuring challenging intellectual programs. Information Age Publishing, 10(2).

Honesti, L., \& Djali, N. (2012). Pendidikan kebencanaan di sekolah-sekolah di indonesia berdasarkan beberapa sudut pandang disiplin ilmu pengetahuan. Jurnal Momentum, 12(1), 51-56.

Ismail, N. S., \& Harun, J. (2016). (2016). Supporting students' critical thinking with a mobile learning environment: A meta-analysis supporting students' critical thinking with a mobile learning environment. Proceeding of INTED 2016 Conference, 3746-3755. https://doi.org/https://doi.org/10.21125/ inted.2016.18 99

Labibah, U. N., Wilujeng, I., Sulaiman, S., \& Rahmawati, L. (2019). Androidbased physics learning media integrated landslide disaster. Jurnal Ilmiah Pendidikan Fisika Al-Biruni, $8(2)$, 229-236. https://doi.org/10.24042/jipfalbiruni.v0 i0.4695

Marhadini, S. A. K., Isa Akhlis, \& Sumpono, I. (2017). Pengembangan media pembelajaran berbasis Android pada materi gerak parabola untuk siswa SMA. UPEJ Unnes Physics Education Journal, 6(3), 38-43. https://doi.org/https://doi.org/10.15294/ upej.v6i3.19315
Mulhayatiah, D., Purwanti, P., Setya, W., Suhendi, H. Y., Kariadinata, R., \& Hartini, S. (2019). The impact of digital learning module in improving students' problem-solving skills. Jurnal Ilmiah Pendidikan Fisika Al-BiruNi, $8(1)$, https://doi.org/https://doi.org/10.24042/ jipfalbiruni.v8 i1.3150

Mustofa, M. H., \& Rusdiana, D. (2016). Profil kemampuan pemecahan masalah siswa pada pembelajaran gerak lurus. Jurnal Penelitian \& Pengembangan Pendidikan Fisika, 2(2), 15-22. https://doi.org/https://doi.org/doi.org/1 0.21009/1.0220 3

Musyarofah, Hindarto, M. (2013). Pendidikan karakter terintegrasi dalam pembelajaran IPA guna menumbuhkan kebiasaan bersikap ilmiah. Unnes Physics Education Journal, 2(2), 4148.

https://doi.org/10.15294/upej.v2i2.2665

Nadian, N., Nik, N., \& Sipon, S. (2015). One-stop center for disaster training information in smartphone platform: A mobile prototype. Journal of Interactive Mobile Technologies, 9(4), $12-16$.

https://doi.org/https://doi.org/10.3991/ij im.v9i4.4418

Parwanto, N. B., \& Oyama, T. (2014). A statistical analysis and comparison of historical earthquake and tsunami disasters in Japan and Indonesia. International Journal of Disaster Risk Reduction, 7(3), 122-141. https://doi.org/https://doi.org/10.1016/j. ijdrr.2013.10. 003

Putranto, T. T., \& Susanto, N. (2017). Pilot implementation of human-centered model in disaster management. Indonesian Journal of Geography, 49(2), 155-164. https://doi.org/10.22146/ijg.15943

Rahmawati, L., Labibah, U. N., \& Kuswanto, H. (2020). The implementation of Android-based physics learning media integrated with 
landslide disaster education to improve critical thinking ability and disaster preparedness. Journal of Physics: Conference Series, 1440(1), 1-6. https://doi.org/10.1088/17426596/1440/1/012042

Rany, T. D., Kuswanto, H., \& Abdillah, A. J. (2020). Development of physicsbased learning media for Android integrated with earthquake disaster education. Journal of Physics: Conference Series, 1440(1), 1-6. https://doi.org/10.1088/17426596/1440/1/012029

Septikasari, Z. (2018). Strategi integrasi pendidikan kebencanaan dalam optimalisasi ketahanan masyarakat menghadapi bencana erupsi gunung merapi. Jurnal Ketahanan Nasional, 24(1), https://doi.org/http://dx.doi.org/ 47-59. 10.22146/jkn.33142

Setiawati, Rusilowati, \& Khumaedi. (2013). Pembuatan buku cerita IPA yang mengintegrasikan materi kebencanaan alam untuk meningkatkan literasi membaca dan pembentukan karakter. Jurnal Pendidikan IPA Indonesia, 2(2), 129-135.

Sugiyono. (2012). Metode Penelitian
Kuantitatif Kualitatif dan $R \& D$. Alfabeta.

Surayya, L., Subagya, I., \& Tika, I. (2014). Pengaruh model pembelajaran think pair share terhadap hasil belajar IPA ditinjau dari keterampilan berpikir kritis siswa. Jurnal Pendidikan Dan Pembelajaran IPA Indonesia, 4(1), 111.

Syuaib, M. Z. (2013). Pengaruh strategi pembelajaran simulasi vs bermain peran dan sikap siswa terhadap pengetahuan dan kesiapsiagaan tentang bencana alam. Jurnal Pendidikan Humaniora, 1(2), 177-189.

Thalheimer, W., \& Cook, S. (2002). How to calculate effect sizes published research: A simplified methodology. A Work Learning Research Publication.

Wimbardana, R., \& Sagala, S. A. H. (2013). Kesiapsiagaan masyarakat terhadap bahaya lahar dingin gunung merapi. Jurnal Bumi Lestari, 13(2), 394-406.

Winarni, E. W., Purwandari, E. P., \&, \& Hervianti, Y. (2018). Hervianti, Y. (2018). Mobile educational game for earthquake disaster preparedness in elementary school. Journal of Engineering and Applied Sciences, 13(7), 2612-2618. 